\title{
Histological and Histochemical Features Of the Jejunum in Wild Turkey Meleagris Gallopavo (Linnaeu, 1758)
}

\author{
Ameer M. Taha, ${ }^{1}$ Ali A. Abed, ${ }^{1}$ Mohamed M. A. Abumandour ${ }^{2}$ \\ ${ }^{1}$ Department of Biology, College of Education for Pure Science, University of Mosul, Iraq. \\ ${ }^{2}$ Department of Anatomy and Embryology, Faculty of Veterinary Medicine, Alexandria University
}

Disclose and conflicts of interest: none to be declared by all authors

\begin{abstract}
Introduction: the present study aimed to identify the histological and histochemistry characterizations of the Jejunum in the wild Turkey Meleagris gallopavo microscopically by using several histological and histochemical stains. The results showed that the jejunum wall is composed of the four layers that make up the wall of the digestive tract. The mucosal layer had a numerous long villus that appeared in various forms. Simple columnar epithelial tissue covers the villi, and this tissue is also rich in goblet cells. The secretory units of Liebrkuhkn's crypts had a spherical shape, some of which contained entroendocrine cells. The Jejunum also was containing Payer's patches. Auerbach's plexus also appeared in the muscularis layer. The histochemical

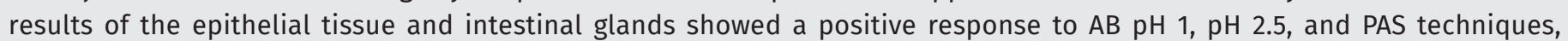
which indicated the secretion of mucous substances. In contrast, the response was negative for BP and SB techniques, which suggests the non-secretion of protein and fatty substances. The study concluded that the jejunum structure is similar to the composition of the rest of the small intestine. Still, it characterized by its multiform villi, entroendocrine cells, and Payer's patches, which contribute significantly to increasing the effectiveness of the digestive tract of this bird.
\end{abstract}

Keywords: Jejunum; Histochemical; Liebrkuhkn's crypts; Payer's patches; Wild Turkey.

\section{Introduction}

The Wild Turkey Meleagris gallopavo (Linnaeu, 1758) is belonged to phasianidae family, Meleagris genus, M. gallopavo species. The Wild Turkey Meleagris gallopavo described as omnivorous bird that prefer to eat to nuts, walnuts, and other hard tree products such as hazelnuts, chestnut and also seeds and grasses in additions to insects and occasionally eat the small reptile as lizards (DICKSON, 1992). So, they prefer to habitat the area have the hardwoods and the mixed coniferous with sparse opening like pastures, fields, orchards, and the seasonal swamps. The Wild Turkey Meleagris gallopavo appears to be able to adapt to any dense local vegetarian community (BIRDLIFE INTERNATIONAL, 2016).

Food plays a vital role in the daily life of animals in general, and vertebrates, and food contributes to maintaining the body and its health because food contains important components that are necessary to increase the growth of the animal and the stability of its internal environment. The process of converting food consumed by the animal into beneficial substances for the body is the function of the digestive system, which analyzes the large molecules present in the food into small particles that are easily absorbed and thus become beneficial to work inside the body (KARDONG, 2006). The digestive system in vertebrates generally consists of several identical regions in general in animals with some differences between different animals on one side and in the animals from the same class on the other side. Wherefore, the anatomical studies of the digestive tract and its specialization in certain parts to perform certain function considered as a key to understand the life style of each bird and consequently the method of taking care of them (HANAFYABUMANDOUR and BASSUONI, 2020). To understand the nutritional ecology of any avian species, it is necessary to studies and understand the anatomical characterizations of their digestive tract (MARTINEZ DEL RIOCORK and KARASOV, 1994).

The small intestine is one of the essential anatomical parts of the digestive system; in birds, it classified into three regions; the duodenum, jejunum, and the ileum (DYCESACK and WENSING, 2010). The duodenum extends from the gizzard to the pancreatic bile ducts, while the jejunum extends from the pancreatic bile ducts to the Meckel's diverticulum that considered as the anatomical landmark between the jejunum and the ileum, moreover the ileum extends from the Meckel diverticulum to the ileocecal junction (GABRIEL et al., 2008, KASPERS and SCHAT, 2012, HANAFYABUMANDOUR and BASSUONI, 2020, DYCESACK and WENSING, 2010). Histologically, the small intestine wall in birds forms from the four primary layers that make up a wall of the digestive tract; the mucosal layer, the submucosal layer, the muscularis 
layer, and the serosa layer. The mucosal layer consists of three secondary sublayers which are; the epithelial tissue, the lamina propria, and the musclaris mucosa. The mucosal layer had the fingerlike processes known as the villi that increase the surface area of absorption. These villi are differing in shape, size, and length in different birds (YAMAUCHIINCHAROEN and YAMAUCHI, 2010, DYCESACK and WENSING, 2010, HANAFYABUMANDOUR and BASSUONI, 2020).

The jejunum is one of the areas of the small intestine, which studies did not focus heavily on, which focused more on the duodenum because of its connection to the stomach and the ileum, posterior part, due to its relationship to the large intestine, so this study came, which aimed to identify the histological structure and histochemistry components of this part of the small intestine in a wild Turkey Meleagris gallopavo using a histological stains and histochemical techniques.

\section{Materials and methods}

\section{Sample's collection}

Twelve birds (6 of each sex) of the wild Turkey Meleagris gallopavo were collected to perform this study. The collected birds were anesthetized with ether, then transferred to the anatomical lab and put on the anatomical plate to open its abdominal region from the middle with accurate scissors according to (WINKER, 2000). The collected samples must be without any alimentary tract abnormalities. The morphological anatomical terms were written following the Nomina Anatomica Avium (NAA) (BAUMEL et al., 1993).

The present investigation was done according to the guidelines of animal welfare and Ethics Committee of the faculty of Education for the Pure Sciences (histology and comparative anatomy laboratory in the Department of Biology), Mosul University and the Faculty of Veterinary Medicine, Alexandria University and following the Egyptian's laws, approved it.

\section{For histological examination}

The histological techniques were performed according to (SUVARNALAYTON and BANCROFT, 2018). The jejunum carefully removed by Precision tweezers, to a petri dish containing a physiological solution with a concentration of (0.75). Briefly, the jejunum cut into small specimens $\left(0.5 \mathrm{~cm}^{3}\right)$ of freshly slaughtered wild Turkey Meleagris gallopavo. The samples were fixed in $10 \%$ neutral buffered formalin. After $24 \mathrm{~h}$, the samples were extensively transferred to $70 \%$ alcohol. The tissue samples were then dehydrated in ascending graded series of ethanol, cleared in xylene, and impregnated and embedded in paraffin wax. Sections of 5-7 $\mu \mathrm{m}$ were cut using Leica rotatory microtome (RM 20352035; Leica Microsystems, Wetzlar, Germany) and mounted on glass slides. The prepared tissue sections were deparaffinized in xylene and rehydrated in descending graded series of ethanol until reaching distilled water.
The current work depend on two stains; the first is the Haematoxylin and Eosin (H\&E) according to (MASSOUD and ABUMANDOUR, 2019) and the Azan stain (AZ) according to (SUVARNALAYTON and BANCROFT, 2018). The sections were analyzed and photographed under the light microscope "Leica Microsystem, Model: DM2500 Wetzlar, Germany" with attached camera manufactured by Leica Microsystem CH-9435 Heerbrugg (DFC290 HD, Germany)".

\section{For histochemical examination}

The following technique was adopted, which are the histochemical techniques included Periodic Acid-Schiff (PAS) technique and Alcian Blue (AB) $\mathrm{pH} 1$ and $\mathrm{pH} 2.5$ techniques, which used to detect carbohydrates (SUVARNALAYTON and BANCROFT, 2018), Bromophenol blue (BP) technique, which used to identify proteins (SCHUMACHER et al., 2004), and Sudan black B (SB) technique, which used to detect lipids (EL-BANHAWYKHATTAB and EL-GANZOURY, 1996, SHEEHAN and HRAPCHAK, 1987).

\section{Results}

\section{Histological observations}

Histologically, the jejunal wall consisted of tunica mucosal, tunica submucosal, tunica musculosa and tunica serosa. The mucosal layer in the jejunum had numerous villi that lined by simple columnar epithelium with goblet cells with different form, which appeared as protrusions that extend toward the lumen of the jejunum. The different forms of these villi were; a finger-like shape, which is the most common form, as well as the conical, rectangular, and triangular. Some villi appeared with a single base and a branched end. Most villi were distinguished by being long and occupying most of the jejunum cavity, although some torn during microscopic preparation. Their length reached $(574.057 \pm 7.325 \mu \mathrm{m})$, and villi in all their forms appeared relatively thick (Fig. 1), and their thickness average was $(100.730 \pm 3.341 \mu \mathrm{m})$.

The villi coated from the outside with a nonciliated simple columnar epithelial tissue whose cells were tightly bound together. The average length of these cells $(18.047 \pm 1.635 \mu \mathrm{m})$ and their thickness $(4.998 \pm 0.325 \mu \mathrm{m})$, the nuclei of these cells were characterized by their oval shape and located in the base of the cell. The free plasma membrane of these cells had microvilli surrounding the villi in whole and appearing clearly in most tissue sections, the average length of these microvilli $(5.243 \pm 2.763 \mu \mathrm{m})$. These cells were based on a basement membrane that is straight in some parts of the jejunum and winding in others and appeared in some parts clearly and unclear in other regions. Also found among epithelial tissue cells, the secretory goblet cells that appeared in a huge number and with secretory vesicles in a significant way, especially using histochemical techniques. These cells also distinguished that their numbers increase 
directly from the bottom of the villi towards the top of it, in some areas, the number of villi at the apex is higher than the epithelial cells (Fig. 2A). The villi lined from the inside under the epithelial tissue, part of the lamina propria, which is known as the lamina propria cone, which forms the core of the villi and its supporting structure. This cone consists of loose connective tissue rich in collagen and muscle fibers, lymphocytes, and blood vessels that have appeared throughout the villi, and the diameters of these blood vessels are different (Figs. 1A, 1C-D, and 2A).

The lamina propria, which located under the villi, is composed of a loose connective tissue, which is also rich in blood vessels and muscle fibers, as well as lymphocytes, which appeared significantly among the components of the lamina propria (Figs. 1A-C, and 2B). The lamina propria also contains the intestinal glands or Liebrkuhkn's crypts, which appeared as branched tubular glands, and its secretory units spread below the villi in one row in some parts and more than one row in other regions. These secretory units were spherical, and their average diameter $(50.483 \pm 4.114 \mu \mathrm{m})$ and their secretions were subtracted directly into the lumen of the jejunum in the spaces between the villi. The secretory cells were inside these units, clearly at the top of these cells, as well as the lumen of secretory units. The secretory cells within these units form a columnar, and its nuclei are spherical and located in the base of cells with an average diameter $(5.243 \pm 0.652 \mu \mathrm{m})$. These cells distinguished by their secretory vehicles, and this is clearly shown at the top of these cells as well as in the lumen of the secretory units (Figs. 1A, 2B, and 2C).

It was also noted in some secretory units the presence of entroendocrine cells that are triangular cells and central oval nucleus. While the muscularis mucosa layer is a network of smooth muscle fibers that extend between the components of the lamina

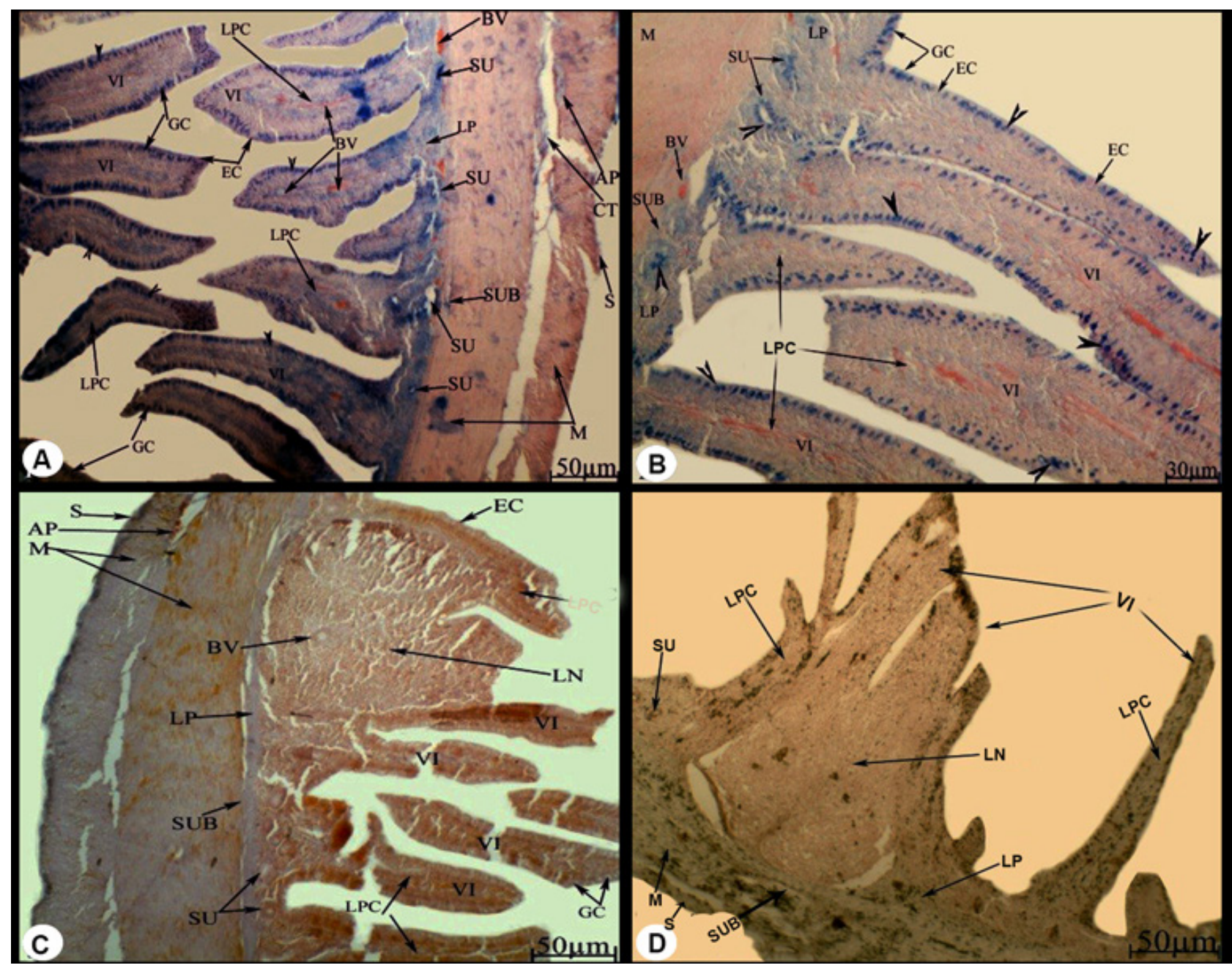

Figure 1. Histological micrograph of the jejunum of the wild Turkey Meleagris gallopavo. View $(A)$ represent the cross section in the jejunal wall. Stained by $A B \mathrm{pH} 1$ technique. View $(B)$ represent the cross section in the jejunal wall. Stained by $\mathrm{AB} \mathrm{pH} 2.5$ technique. View (C) represent the cross section in the jejunal wall. Stained by AZ stain.

View D) represent the cross section in the jejunal wall. Stained by SB technique. Abbreviations:

Muscularis externa (M); Submucosa (SUB); Serosa (S); Auerbach's plexus (AP); Secretory units (SU); Lamina propria cone (LPC); Villi (VI); epithelial cells (EC); Goblet cells (GC); Nucleus (N); Brush border (BB); Lamina propria (LP); Muscles fibers (MF); Entroendocrine cells (EN); Blood vessels (BV); connective tissue (CT); lymph nodules (LN); lymphocyte (L); collagen fibers (CF); small lymph nodules (SLN); positive response to the technique (arrowhead). 
propria and surround the secretory units of the intestinal glands and to support them and stretch as well toward the lamina propria cone within the villi (Fig. 2B-C). Also appeared in the jejunum of this bird, the lymph nodules or Payer's patches, consisting of a group of lymphoid tissue under two or more villi that become surrounded by the outside by the epithelial tissue of the villi. In contrast, the core of these nodules composed of a very large number of lymphocytes and other components of lymphoid tissue as well as blood vessels and lymphoid, as it was noted that these nodules contain smaller lymph nodes within them, which appeared in the form of circular clusters of lymphocytes that are isolated from the rest of the nodule with their shell (Figs. 1C$\mathrm{D}$, and 2D).
The submucosal layer appeared in a thin layer under the mucosa layer consisting of loose connective tissue in some areas and dense in other areas rich in blood vessels and collagen fibers. The muscularis layer appeared as a thick muscle layer consisting of two sub-layers. The first being in the form of smooth circular muscles, and their muscles in the way of tightly packed bundles with an average thickness of $(227.324 \pm 5.275 \mu \mathrm{m})$, while the second muscle layer was a longitudinal arrangement with an average width $(118.864 \pm 4.923 \mu \mathrm{m})$ separated by a thin layer from connective tissue rich in blood and lymphatic vessels, as well as the Auerbach's plexus appeared between the two muscular layers. The serosa layer composed form a simple squamous tissue surrounding a loose connective tissue (Fig. 1).

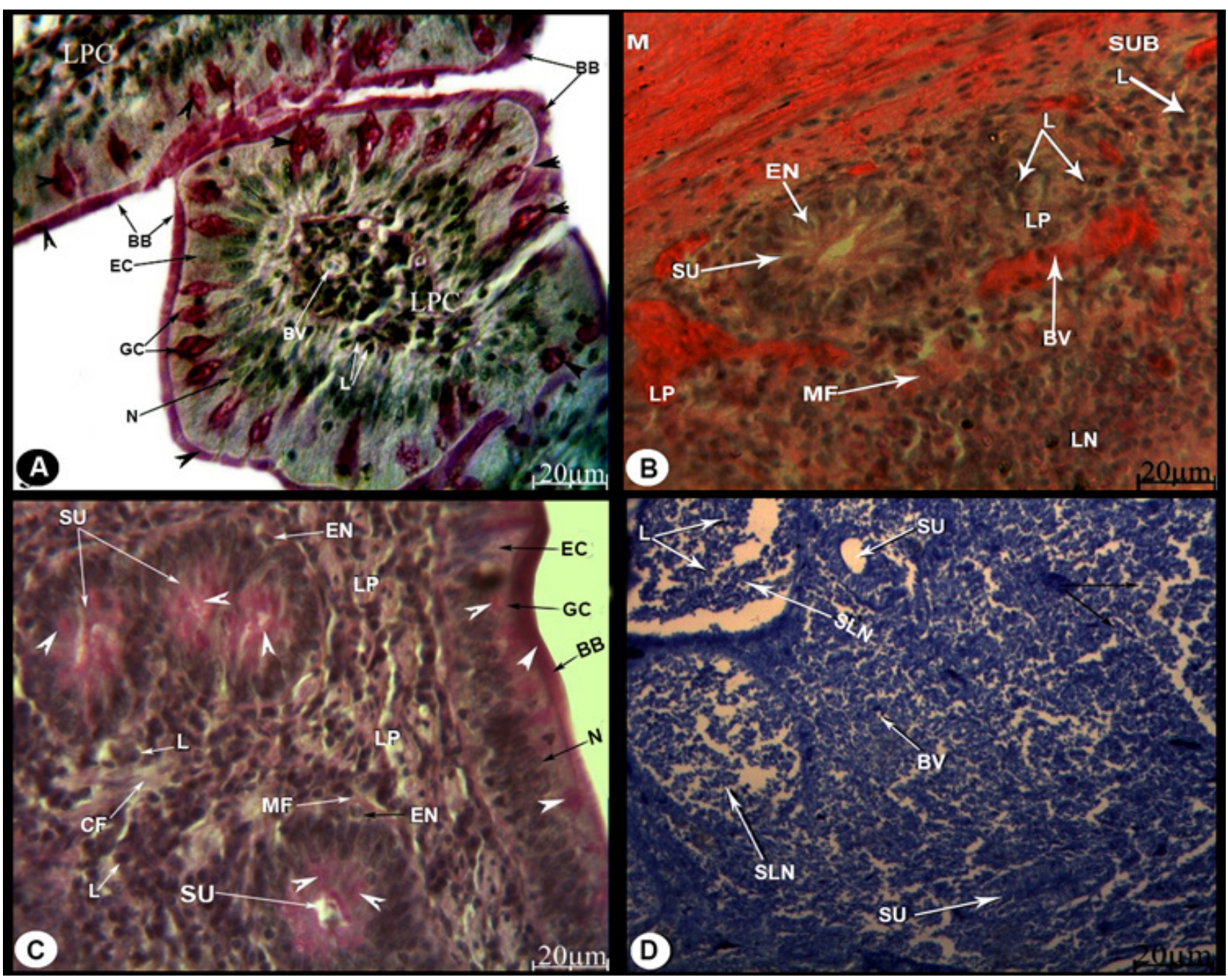

Figure 2. Histological micrograph of the jejunum of the wild Turkey Meleagris gallopavo. View (A) represent the cross section in the jejunum villi. Stained by PAS technique.

View (B) represent the cross section in the jejunum lamina propria. Stained by H\&E stain. View (C) represent the cross section in the jejunum lamina propria. Stained by PAS technique.

View (D) represent the cross section in the jejunum lymph nodule. Stained by BP technique.

Abbreviations:

Muscularis externa (M); Submucosa (SUB); Serosa (S); Auerbach's plexus (AP); Secretory units (SU); Lamina propria cone (LPC); Villi (VI); epithelial cells (EC); Goblet cells (GC); Nucleus (N); Brush border (BB); Lamina propria (LP); Muscles fibers (MF); Entroendocrine cells (EN); Blood vessels (BV); connective tissue (CT); lymph nodules (LN); lymphocyte (L); collagen fibers (CF); small lymph nodules (SLN); positive response to the technique (arrowhead). 


\section{Histochemical observations}

The histochemical observations showed the response of the epithelial cells and intestinal glands to the histochemical techniques used. The Table (1) indicated that the epithelial cells and goblet cells appeared medium positive response in some regions and strong in the other for $\mathrm{AB}$ pH 1 and $\mathrm{AB} \mathrm{pH} 2.5$ techniques, this indicated that these cells and their secretions were rich in the different amounts of weak acidic and strong acidic mucous materials (Fig. 1AB). Also, Table (1) shown a strong positive response to the PAS technique in the cells of this tissue and its secretion, and the edge of the border brush and the secretory vesicles were of strong red color that indicated the secretory efficacy of the mucous substances containing polysaccharides (Fig. 2A-B). Whereas, Table (1) shown a negative response to both BP technique and SB technique, and this indicated the lack of secretion of protein or fatty substances in this tissue.

Table 1. the response of jejunum to the histochemical techniques

\begin{tabular}{c|c|c}
\hline Tissue & $\begin{array}{c}\text { The epithelial } \\
\text { tissue }\end{array}$ & Intestinal glands \\
\hline $\mathrm{AB} \mathrm{pH} 1$ & +++ & ++ \\
\hline $\mathrm{AB} \mathrm{pH} 2.5$ & ++ & ++ \\
\hline $\mathrm{PAS}$ & +++ & ++ \\
\hline $\mathrm{BP}$ & - & - \\
\hline $\mathrm{SB}$ & - & - \\
\hline
\end{tabular}

Table (1) also shown a strong positive response to the secretory units of the intestinal glands of $\mathrm{AB} \mathrm{pH} 1$ and $\mathrm{AB}$ pH 2.5 techniques. That response was clear in a cavity in the units, as well as at the top of the secretory cells of the secretory units, which indicated the presence of secretory mucous substances with weak acidic and strong acidic mucous materials in secretions of these glands (Fig. 1A-B). Table (1) also shown the strong response of the PAS technique to secretory units. As is the case of the $A B$ technique, the response appeared clearly in the center of secretory units as well as at the top of secretory cells, which indicated the secretion of mucous substances rich in polysaccharides (Fig. 2C). While Table (1) shown a negative response for both BP technique and SB technique as well, this indicated the lack of secretion of protein or fatty substances in the secretory cells of the intestinal glands.

\section{Discussion}

The current histological observations clarify that, the jejunum in Wild Turkey Meleagris gallopavo are similar to that described in all avian species (LEVI et al., 2013, NASRIN et al., 2012, ZGHAIR and KHALEEL, 2019, KUSHCH et al., 2019, PARISAKHOJASTE and MAHDI, 2019, HANAFYABUMANDOUR and BASSUONI,
2020) whilst, the transition zone that landmark between the jejunum and ileum could not recognized in the black-winged kite Elanus caeruleus (HAMDI et al., 2013). The jejunal wall consisted of four layers that make up the wall of the gut in all vertebrate species including the birds (PARISAKHOJASTE and MAHDI, 2019, ZAHER et al., 2012b, AL-A'ARAJI and AL-KAFAGY, 2016. HANAFYABUMANDOUR and BASSUONI, 2020, EL-MANSIAL-KAHTANI and ABUMANDOUR, 2019).

There is a little variation in the shape of the jejunal villi between the different avian species and also this variation was appeared in the same bird species. The current histological examinations in Wild Turkey Meleagris gallopavo observed the presence of numerous appearances of the jejunal villi; the finger-like type is the dominant one, the conical, rectangular, and triangular. The finger-like type of the jejunal villi were similar to what appeared in the most of the different previously studied birds as in pheasant, African Ostrich, Coturnix coturnix and other birds (LEVI et al., 2013, NASRIN et al., 2012, PARISAKHOJASTE and MAHDI, 2019, ZAHER et al., 2012b, ALHOMAID and ALI, 2013), while (HANAFYABUMANDOUR and BASSUONI, 2020) observed the presence of the triangular jejunal villi in the Garganey Anas querquedula. Moreover, the current work reported the presence of the long villi (NASRIN et al., 2012). Moreover, the geese of the Gorkovskaya breed had the highest jejunal villi height and surface area (KUSHCH et al., 2019).

The functional anatomical presence of the villi in all small intestinal parts including the jejunum to increase the lumen surface area of the small intestine and consequently increase the absorption mechanism of the digested materials (SCHAEFER et al., 2006, DYCESACK and WENSING, 2010) who added that the increase in the height and width of the villi will increases the absorption surface area and lead to increase the growth and production. Also, longer villi indicate increased epithelial progenitor proliferation and decreased epithelial turnover (GODWINCLIFFORD and AGATHA, 2016).

The present observation of the Wild Turkey Meleagris gallopavo clear that the jejunal villi was lined by the simple columnar epithelial tissue, like the noticed observation in numerous bird species (AL-JERAISY, 2017, AL-DULEEMY, 2019, HANAFYABUMANDOUR and BASSUONI, 2020). The current histological examination described the presence of secretory cells that increase in number at the top of villi, like that noticed by (ALHOMAID and ALI, 2013, NASRIN et al., 2012, PARISAKHOJASTE and MAHDI, 2019, HUSSEIN and REZK, 2016b, HANAFYABUMANDOUR and BASSUONI, 2020, KHALEEL and ATIEA, 2017). Perhaps the reason for the presence of a large number of these cells at the end of the digestive tract to increase the secretion of mucous to facilitate the passage of waste products, This explanation come to an agreement with that discussed in the falcon (HAMDI et al., 2013, 
AL-TAEE, 2017) and (HANAFYABUMANDOUR and BASSUONI, 2020) in the Garganey (Anas querquedula).

The current histological studies in the Wild Turkey Meleagris gallopavo described that the lamina propria and the lamina propria cone consisted of a loose connective tissue rich in the blood vessels, corresponding to that noticed by (HUSSEIN and REZK, 2016b). Moreover, the current work observed the presence of the intestinal glands or Liebrkuhkn's crypts in the lamina propria. These glands contribute to the digestion of food nutrients, which is what appeared in the rest of the birds (AL-DULEEMY, 2019, AL-JERAISY, 2017, GODWINCLIFFORD and AGATHA, 2016, HANAFYABUMANDOUR and BASSUONI, 2020).

The current work observed the presence of the entero-endocrine cells in the Wild Turkey Meleagris gallopavo as noted in the cattle egret Bubulcus Ibis (HUSSEIN and REZK, 2016b), moreover these cells also appeared in the rabbit jejunum (ABDUMUTALOVICH, 2017). The jejunum also distinguished by the presence of Payer's patches, which contributes to the defensive function of the bird's body against pathogenic organisms and other pathogens, and these nodules also appeared in pheasant (PARISAKHOJASTE and MAHDI, 2019) and (HANAFYABUMANDOUR and BASSUONI, 2020) in the Garganey Anas querquedula.

The current histological results of the rest of the jejunal wall layers appeared similar to the previously examined birds, as in the Kestrel Falco tunniculus and white eared bulbul Picnonotic leucotis, pheasant Phasianus colchicus, cattle egret Bubulcus Ibis, Garganey Anas querquedula (AL-A'ARAJI and AL-KAFAGY, 2016, HUSSEIN and REZK, 2016b, PARISAKHOJASTE and MAHDI, 2019, HANAFYABUMANDOUR and BASSUONI, 2020). It reported that the tunica muscularis is involved in peristaltic movement activities that propel the intestinal contents towards the large intestine. In the African pied crow, the tunica muscularis of the jejunum was thicker than that of the duodenum and ileum, respectively, and this indicates a higher percentage of digestion and absorption takes place in the jejunum (GODWINCLIFFORD and AGATHA, 2016). The current work noted that the muscularis layer consisted of thick inner circular layer and outer thin longitudinal layer of smooth muscle fibers, this corresponding to that observed by (HUSSEIN and REZK, 2016a, RODRIGUES et al., 2012, ABD EL- AZIZ, 1984, ZAHER et al., 2012a, HANAFYABUMANDOUR and BASSUONI, 2020).

The current histochemical observations clarify that the epithelial tissue and the intestinal glands showed a positive response for $\mathrm{AB}$ and $\mathrm{PAS}$ techniques, that indicated the presence of carbohydrate and mucous substances in their secretions, which corresponding to that reported in pin-tailed sandgrouse Pterocles alchata, starling Sturnus vulgaris, African ostrich Struthio Camelus, cattle egret Bubulcus Ibis and zebra finch (AL-DULEEMY, 2019, ALHOMAID and ALI, 2013, AL-JERAISY, 2017, HUSSEIN and REZK, 2016b, TAKI-EL-DEEN, 2017). While, it appeared negative for crystalline cells in a Kestrel Falco tunniculus (AL-A'ARAJI and AL-KAFAGY, 2016), it is known that the goblet cells produce mucous secretions that contain neutral and acidic mucopolysaccharides (GODWINCLIFFORD and AGATHA, 2016). This mucus secreted by the goblet cells may play a different roles including, a medium for absorptive processes take place, enhancement the contents movement (digesta) and nutrients digestibility, protection of the mucosal surface from the chemical irritants, microorganisms and abrasion, providing a smooth, lubricated mucosal surface that facilitates the movement of the contents and contributing to the energy requirements of the microvilli and epithelial cells for breakdown and absorption of the intestinal contents (PARISAKHOJASTE and MAHDI, 2019, ZGHAIR and KHALEEL, 2019), while, shown negative response to the techniques of BP and SB and this indicated that there were no clusters or secretions of protein and fatty substances, which also documented in the rest of the birds.

\section{Conclusions}

We can conclude from the current study that the structure of the jejunum is similar to the rest of the small intestine and characterized by the presence of lymph nodules that contribute to the defense of the bird's body. The jejunal villi had a different appearance but the finger-like shape is the common form. The jejunum also contributes to carbohydrates and mucous secretions that help the digestive system to perform its functions correctly.

\section{Acknowledgments}

The authors would like to thank the Presidency of the University of Mosul, especially the President of the University of Mosul, Prof. Dr. Qusay Kamal Al-Din Al-Ahmadi, as well as the Deanship of the Faculty of Education for Pure Sciences for facilitating the use of laboratories and laboratory tools, as well as providing chemicals for research. 


\section{References}

Abd El- Aziz, I. 1984. Comparative macroscopic and microscopic anatomy on the digestive system of some vertebrate animals. Ph.D. Thesis. Zoology Department, Faculty of Science, Al-Azhar Univ., Cairo. Place Publised.

Abdumutalovich, PO. 2017. Morphology of neuroendocrineimmune system of jejunum in early postnatal ontogenesis. European science review:100-102.

Al-a'Araji, AS, and SM Al-Kafagy. 2016. A comparative anatomical, histological and histochemical study of small intestine in Kestrel (Falco tunniculus) and white eared bulbul (Picnonotic leucotis) according to their food type. The Iraqi Journal of Veterinary Medicine 40:36-41.

Al-Duleemy, AS. 2019. Comparative Anatomical and histological study of the Digestive canal and histochemistry of the mucin in two types of birds. Master Thesis, College of Education for Pure Sciences, University of Mosul, Iraq. (thesis in Arabic with an abstract in English). Place Publised.

Al-Jeraisy, FN. 2017. Anatomical histological study and histochemical comparison of the digestive system in three types of vertebrates belonging to three different classes. Master Thesis, College of Education for Pure Sciences, University of Mosul, Iraq. (thesis in Arabic with an abstract in English). Place Publised.

Al-Taee, A. 2017. Macroscopic and microscopic study of digestive tract of brown falcon Falco berigora in Iraq. JUBPAS 25:915-936.

Alhomaid, FA, and HA Ali. 2013. Histological observations on the proventriculus and duodenum of African ostrich (Struthio Camelus) in relation to dietary vitamin A. Life Sci. J 10:479-486.

Baumel, JJ, SA King, JE Breazile, HE Evans, and JCV Berge. 1993. Handbook of avian anatomy: Nomina Anatomica Avium. 2nd ed. . Cambridge: Nuttall Ornithological Club. 779p. 1993.Page.

Birdlife International. 2016. Meleagris gallopavo". IUCN Red List of Threatened Species. 2016: e.T22679525A92817779. doi:10.2305/IUCN. UK.2016-3.RLTS.T22679525A92817779.en. 2016.Page.

Dickson, JG. 1992. The wild turkey: biology and management: Stackpole Books. 1992.Page.

Dyce, KM, WO Sack, and CJG Wensing. 2010. Text book of Veterinary anatomy.: W.B. Saunders Company, Philadelphia, London and Toronto. 2010.Page.

El-Banhawy, MA, FI Khattab, and MA El-Ganzoury. 1996. The foundations of theoretical and practical histochemistry. Academic Library. Cairo. Egypt. (book in Arabic with a title in English). 1996.Page

El-Mansi, AA, M Al-Kahtani, and MM Abumandour. 2019. Comparative phenotypic and structural adaptations of tongue and gastrointestinal tract in two bats having different feeding habits captured from Saudi Arabia: Egyptian fruit bat (Rousettus aegyptiacus) and Egyptian tomb bat (Taphozous perforatus). Zoologischer Anzeiger 281:24-38.

Gabriel, I, S Mallet, M Leconte, A Travel, and JP Lalles. 2008. Effects of whole wheat feeding on the development of the digestive tract of broiler chickens. Animal Feed Science and Technology 142:144-162 Godwin, OC, AN Clifford, and A Agatha. 2016. Evaluation of the morphological adaptations of the small intestine of the African pied crow (Corvus.

Hamdi, H, A El-Gareeb, M Zaher, and A Abuamod. 2013. Anatomical,histological and histochemical adaptations of avian alimentary canal to their food habits. II-Elanus caeruleus. Int. J. Sci. \&En. Res. 4:1355-1364.

Hanafy, BG, MMA Abumandour, and NF Bassuoni. 2020. Morphological features of the gastrointestinal tract of Garganey (Anas querquedula, Linnaeus 1758)-Oesophagus to coprodeum. Anat Histol Embryol 49:233-250.

Hussein, S, and H Rezk. 2016a. MACRO AND MICROSCOPIC CHARACTERISTICS OF THE GAST-ROINTESTINAL TRACT OF THE CATTLE EGRET (BUBULCUS IBIS). Int J Anat Res 4:2162-74.

Hussein, S, and H Rezk. 2016b. Macro and microscopic characteristics of the gastrointestinal tract of the cattle Egret (BUBULCUS IBIS).
International Journal of Anatomy and Research 4:2162-2174.

Kardong, KV. 2006. Vertebrates: comparative anatomy, function, evolution: McGraw-Hill New York. 2006.Page

Kaspers, B, and KA Schat. 2012. Avian Immunology: Elsevier Science. 2012.Page.

Khaleel, IM, and GD Atiea. 2017. Morphological and histochemical study of small intestine inindigenous ducks (Anas platyrhynchos). IOSR Journal of Agriculture and Veterinary Science 10:19-27

Kushch, MM, LL Kushch, EV Byrka, VV Byrka, and OS Yaremchuk. 2019. Morphological features of the jejunum and ileum of the middle and heavy goose breeds. Ukrainian Journal of Ecology 9:690-694

Levi, UI, OC Lilian, N Adaka, E Onyiche, CI Nwaogu, and ND Ezeasor. 2013. Gross and Histomorphometric Changes in the Small Intestine of Anak and Marshal Broiler Hybrids. Indian Journal of Veterinary Anatomy 25:76-78.

Martinez Del Rio, C, SJ Cork, and WH Karasov. 1994. Modelling gut function: an introduction. In: The Digestive System in Mammals Food, Form and Function (D. J. Chivers and P. Langer, eds). Cambridge: Cambridge University Press, pp. 25-53. 1994.Page.

Massoud, D, and MMA Abumandour. 2019. Descriptive studies on the tongue of two micro-mammals inhabiting the Egyptian fauna; the Nile grass rat (Arvicanthis niloticus) and the Egyptian long-eared hedgehog (Hemiechinus auritus). Microsc Res Tech 82:1584-1592

Nasrin, M, MN Siddiqi, MA Masum, and MA Wares. 2012. Gross and histological studies of digestive tract of broilers during postnatal growth and development. J. Bangladesh Agril. Univ. 10:69-77

Parisa, B, B Khojaste, and S Mahdi. 2019. Morpho-histology of the alimentary canal of pheasant (Phasianus colchicus). Online Journal of Veterinary Research 23:615-627.

Rodrigues, M, J Abreu, C Tivane, P Wagner, D Campos, R Guerra, R Rici, and M Miglino. 2012. Microscopical study of the digestive tract of Blue and Yellow macaws. Current Microscopy Contributions to Advances in Science and Technology (A. Méndez-Vilas, Ed.):414-421.

Schaefer, C, C Corsiglia, A Mireles Jr, and E Koutsos. 2006. Turkey breeder hen age affects growth and systemic and intestinal inflammatory responses in female poults examined at different ages posthatch. Poultry science 85:1755-1763.

Schumacher, U, M Duku, M Katoh, J Jörns, and WJ Krause. 2004. Histochemical similarities of mucins produced by Brunner's glands and pyloric glands: A comparative study. Anat Rec 278:540-550

Sheehan, D, and B Hrapchak. 1987. Theory and Practice of Histotechnology, ; Columbus. OH-Battelle Memorial Institute

Suvarna, KS, C Layton, and JD Bancroft. 2018. Bancroft's theory and practice of histological techniques E-Book: Elsevier Health Sciences. 2018.Page.

Taki-El-Deen, F. 2017. Histological and histochemical studies on the alimentary canal of spur-winged lapwing vanellus spinosus. The Egyptian Journal of Hospital Medicine 67:314-321

Winker, K. 2000. Obtaining, preserving, and preparing bird specimens. Journal of Field Ornithology 71:250-297.

Yamauchi, KE, T Incharoen, and K Yamauchi. 2010. The relationship between intestinal histology and function as shown by compensatory enlargement of remnant villi after midgut resection in chickens. The Anatomical Record: Advances in Integrative Anatomy and Evolutionary Biology 293:2071-2079.

Zaher, M, A-W El-Ghareeb, H Hamdi, and F Abuamod. 2012a. Anatomical, histological and histochemical adaptations of the avian alimentary canal to their food habits: I-Coturnix coturnix. Life Sci. J 9:253-275.

Zaher, M, A El-Ghareeb, H Hamdi, and F Abuamod. 2012b. Anatomical, histological and histochemical adaptations of the avian alimentary canal to their food habits:I-Coturnix coturnix. Life Sci. J 9:253-275 Zghair, FS, and IM Khaleel. 2019. Morphometrical Study of Small Intestine in the Adult Guinea Fowl (Numidia meleagris). Indian Journal of Natural Sciences. 9:16965- 16974. 
Received: August 8, 2019

Accepted: Abril 6, 2020
Corresponding author

Mohamed M. A. Abumandour

E-mail: m.abumandour@yahoo.com 